11. Casper RF. Aromatase inhibitors in ovarian stimulation. $J$ Steroid Biochem Mol Biol 2007; 106: 71-5.

12. Lambalk CB, Huirne JAF, Macklon NS, Fauser BCJM, Homburg R. Ovulation induction with clomiphene or gonadotropins. International Congress Series 2005; 1279: 16-23.

13. Barroso G, Menocal G, Felix H, Roja-Ruiz JC, Arslan M, Oehninger S. Comparison of the efficacy of the aromatase inhibitor Letrozole and clomiphene citrate as adjuvants to recombinant follicle-stimulating hormone in controlled ovarian hyperstimulation: a prospective, randomized, blinded clinical trial. Fertil Steril 2006; 86: 1428-31.
14. Dickey RP, Holtkamp DE. Development, pharmacology and clinical experience with clomiphene citrate. Hum Reprod update 1996; 2: 483-506.

15. National Institute of Clinical Excellence. Ovulation disorders. Fertility: assessment and treatment for people with fertility problems. London, RCOG press 2013: 139182.

16. Biljan MM, Tan SL, Tulandi T. Prospective randomized trial comparing the effects of 2.5 and $5.0 \mathrm{mg}$ of Letrozole on follicular development, endometrial thickness and pregnancy rate in patients undergoing super-ovulation.

\title{
Environmental and occupational exposures as a cause of male infertility
}

\author{
G U S Wijesekara', D M S Fernando ${ }^{2}$, S Wijerathna ${ }^{4}$, N Bandara ${ }^{3}$
}

(Index words: environmental and occupational exposure, lead/cadmium in seminal plasma, semen parameters)

\begin{abstract}
Objectives To determine the association between environmental and occupational exposures, semen parameters and lead $(\mathrm{Pb})$ and cadmium $(\mathrm{Cd})$ levels in seminal plasma of men investigated for infertility.

Methods Data were collected from 300 men investigated for infertility using an interviewer administered questionnaire. Seminal fluid analysis and classification was done according to WHO guidelines. Positive exposure was defined as environmental or occupational exposure to agro or industrial chemicals, heavy metals and living in areas within $50 \mathrm{~m}$ of potential sources of pollution for three months or more. Seminal plasma lead and cadmium levels were estimated by graphite furnace atomic absorption spectrophotometry after digestion with nitric acid. The means of sperm parameters, $\mathrm{Pb}$ and $\mathrm{Cd}$ concentrations between exposed and non exposed groups were compared using t-test.
\end{abstract}

Results Mean age was $34.8(95 \% \mathrm{Cl} 34.2-35.4)$ years BMI was $24.3(95 \% \mathrm{Cl} 23.8-24.7) \mathrm{kg} / \mathrm{m}^{2}$ and duration of the infertility was 45.7 (41.7-49.6) months. In this study, $54.6 \%$ were exposed to toxins through environmental or occupational sources. All sperm parameters were lower in the exposed group when compared to the non exposed. Lead and cadmium were detected in $38.3 \%$ and $23 \%$ of men respectively. The distance from the source of possible environmental or occupational exposure was negatively correlated to seminal plasma $\mathrm{Pb}(\mathrm{r}=0.06, p>0.05)$ and $\mathrm{Cd}$ $(r=0.26, p<0.05)$ concentrations. In the exposed, mean lead concentration was 17.7 (95\% Cl 15.0-20.4) $\mu \mathrm{g} / \mathrm{dl}$ and $13.5(95 \% \mathrm{Cl} 11.2-15.7) \mu \mathrm{g} / \mathrm{dl}$ in non exposed and cadmium concentration in exposed was $1.2(95 \% \mathrm{Cl} 1.1$ $1.4) \mu \mathrm{g} / \mathrm{dl}$ and $1.1(0.9-1.3) \mu \mathrm{g} / \mathrm{dl}$ in non-exposed.

Conclusions Environmental and occupational exposures were associated with reduced sperm count motility, viability, normal forms and detectable levels of lead and cadmium in seminal plasma.

Ceylon Medical Journal 2015; 60: 52-6

\section{Introduction}

Globally, human fecundity appears to be on the decline with decrease in semen quality and male infertility being on the rise $[1,2]$. Environmental pollutants, occupational exposures and life style factors have been explored as possible contributors [3]. Toxicants affecting the reproductive system are broadly categorised as petroleum products, agrochemicals, industrial chemicals and heavy metals. The effects of exposure to toxicants and male infertility have been reported by many investigators [4]. However the results vary according to the study population, the methods used in the assessment of exposure and the biological end point.

Of the heavy metals known to impair semen quality, lead $(\mathrm{Pb})$ and cadmium $(\mathrm{Cd})$ are the two most prevalent

Departments of ${ }^{1}$ Health Science, ${ }^{2}$ Physiology and ${ }^{3}$ Forestry and Environmental Sciences, University of Sri Jayewardenepura and ${ }^{4}$ Department of Obstetrics and Gynecology, Faculty of Medicine, University of Colombo, Sri Lanka.

Correspondence: GUSW, e-mail: <udaya.wije@gmail.com>. Received 29 June 2014 and revised version accepted 10 January 2015. 
in the environment [5]. During the past few decades $\mathrm{Pb}$ and $\mathrm{Cd}$ levels in the environment have increased due to excessive use of gasoline and petroleum products, rapid industrialisation and smoking. Thus exposure to these heavy metals occurs through contaminated water, food and air. Once absorbed into the blood $\mathrm{Pb}$ and $\mathrm{Cd}$ are deposited in bone, kidney and reproductive organs.

In Sri Lanka too there is evidence that contamination of water, soil and air with $\mathrm{Pb}$ and $\mathrm{Cd}$ is high [6]. However, the effects of exposure to heavy metals on male fertility have not been studied. Hence this study aims to describe the association between environmental and occupational exposures with semen parameters and $\mathrm{Pb}$ and $\mathrm{Cd}$ levels in seminal plasma of men investigated for infertility.

\section{Methods}

Male partners $(n=300)$ of couples investigated for infertility between August 2010 to March 2012 were recruited. Males with known causes of infertility were excluded. Obtaining information and seminal fluid analy-sis were done at Vindana Reproductive Health Centre, Colombo, while $\mathrm{Pb}$ and $\mathrm{Cd}$ in seminal plasma were measured at the Coconut Development Authority, Sri Lanka.

Demographic data and information regarding environmental and occupational exposures were collected using an interviewer administered questionnaire after obtaining informed written consent. Men living in areas less than $50 \mathrm{~m}$ from a main road or from an industry emanating toxicants were considered environmentally exposed. Occupational exposure was defined as men reporting contact with chemicals and other potentially hazardous substances at work places such as welding, painting, printing, and farmers using agrochemicals. Three-wheeler drivers and those who rode motor bicycles more than $40 \mathrm{~km}$ a day were also considered positive for occupational exposure. For both environmental and occupational exposures, the minimum duration was three months.

Semen samples were collected after three days of sexual abstinence. Seminal fluid analysis and the categorisation into normozoospermic and pathozoospermic groups were done according to WHO guidelines [7]. Following centrifugation, seminal plasma was stored in metal free, labeled polypropylene plastic tubes at $-20^{\circ} \mathrm{C}$ for subsequent $\mathrm{Pb}$ and $\mathrm{Cd}$ analysis [8].

Lead and cadmium analysis was done by Graphite Furnace Atomic Absorption Spectrophotometry (Varian spectra 250, Australia). A volume of $0.5 \mathrm{ml}$ of seminal plasma was digested in $5 \mathrm{ml}$ of ultrapure grade concentrated $\mathrm{HNO}_{3}$ and $2 \mathrm{ml}$ of $30 \% \mathrm{H}_{2} \mathrm{O}_{2}$ in the teflon digestion vessel (XP 1500 Plus) placed in the microwave oven (Mars 907511, CEM Corp, USA) for 30 minutes. The filtrate was diluted using deionised water. Both control and blank samples were treated in a similar manner for each batch of tests.

The Graphite Furnace Atomic Absorption Spectrophotometer (GFAAS) was calibrated using 10, 20, and $40 \mu \mathrm{g} / \mathrm{l}$ and 1,2 , and $4 \mu \mathrm{g} / \mathrm{l}$ standards (Inorganic Ventures, USA) for $\mathrm{Pb}$ and $\mathrm{Cd}$ respectively. Blank and test samples were aspirated into GFAAS by using wavelengths 283.3 $\mathrm{nm}$ and $228.8 \mathrm{~nm}$ respectively. Both test and control samples were analysed in duplicate and the average was taken as the result. The minimum detection limit for $\mathrm{Pb}$ and $\mathrm{Cd}$ were 0.32 and $0.50 \mu \mathrm{g} / \mathrm{l}$ respectively.

Statistical analysis was done using SPSS (version16). Means of sperm parameters, $\mathrm{Pb}$ and $\mathrm{Cd}$ concentrations in different exposure categories were compared using independent sample t-test. The age and the distance from the source of pollution to residence were correlated with $\mathrm{Pb}$ and $\mathrm{Cd}$ concentrations in seminal plasma using Spearman's correlation. $P$ value $<0.05$ was considered as statistically significant. Approval was obtained from the Ethical Review Committee of the Faculty of Medical Sciences, University of Sri Jayewardenepura. Written informed consent was obtained from the patients.

\section{Results}

The demographics of the total population is given in Table 1. The exposed and the non exposed groups did not differ significantly on mean age, body mass index and duration of infertility.

Table 1. Demographic characteristics of exposed and non exposed groups

\begin{tabular}{lccc}
\hline Characteristic & $\begin{array}{c}\text { Total sample } \\
(n=300) \\
\text { mean }(95 \% C I)\end{array}$ & $\begin{array}{c}\text { Exposed } \\
(n=164) \\
\text { mean }(95 \% C I)\end{array}$ & $\begin{array}{c}\text { Not exposed } \\
(n=136) \\
\text { mean }(95 \% C I)\end{array}$ \\
\hline $\begin{array}{l}\text { Age (years) } \\
\begin{array}{l}\text { Body Mass Index } \\
\left(\mathrm{kg} / \mathrm{m}^{2}\right)\end{array}\end{array}$ & $34.8(34.2-35.4)$ & $34.9(33.9-35.8)$ & $p=0.6$ \\
$\begin{array}{l}\text { Duration of infertility } \\
(\mathrm{months})\end{array}$ & $24.3(23.8-24.7)$ & $23.8(23.2-24.4)$ & $25.1(24.3-25.9)$ \\
\hline
\end{tabular}

\footnotetext{
*Independent sample $\mathrm{t}$ test
} 
Nearly $68 \%$ of the men were from the Western Province and $51 \%$ were from the Colombo district. The other provinces included Central $(6 \%)$, North Central (6\%), Southern (4\%) and North Western (3\%).

Of the men investigated for infertility, 164 (54.6\%) were exposed to toxins through environmental or occupational sources. Of the exposed, 80 (26.6\%) lived in areas with possible environmental toxicity and 112 $(37.3 \%)$ were exposed to toxins through occupational sources. The proportions of exposed toxins are given in Table 2 . A noteworthy proportion $(30.3 \%)$ of men were exposed to petroleum products and of them, $51 \%(\mathrm{n}=46)$ were three wheeler drivers, $29.6 \%(\mathrm{n}=27)$ were men living in areas less than $50 \mathrm{~m}$ from a main road and $20 \%(\mathrm{n}=18)$

\section{Table 2. Exposure to different categories of} toxicants

\begin{tabular}{lc}
\hline $\begin{array}{l}\text { Type of exposure } \\
\text { Pumber of participants } \\
n(\%)\end{array}$ \\
\hline Petroleum products & $91(30.3)$ \\
Industrial chemicals & $50(16.9)$ \\
Agrochemicals & $20(6.8)$ \\
Heat & $10(0.3)$ \\
\hline
\end{tabular}

were men who had direct contact with petroleum products.

The mean values of sperm concentration and normal morphology of exposed pathozoospermic men were significantly lower when compared to non exposed pathozoospermic men while the mean values of sperm progressive motility, normal sperm morphology and sperm viability of exposed normozoospermic men were significantly lower when compared to non exposed normozoospermic men. Sperm with normal morphology was significantly lower in the exposed groups although the mean values were above the reference limit (Table 3 ).

Lead was detected in the seminal plasma in 115 $(38.3 \%)$ and $\mathrm{Cd}$ was present in $69(23 \%)$ of men. Both heavy metals were present in 18 men. In the total population the mean Pd concentration was $15.77 \mu \mathrm{g} /$ $\mathrm{dl}$ and $\mathrm{Cd}$ concentration was $1.18 \mu \mathrm{g} / \mathrm{dl}$. The highest concentration was $\mathrm{Pb} 132 \mu \mathrm{g} / \mathrm{dl}$ and $\mathrm{Cd} 24 \mu \mathrm{g} / \mathrm{dl}$. There was no correlation between the seminal plasma $\mathrm{Pb}$ and $\mathrm{Cd}$ concentration and age. The distance from the area of possible environmental or occupational exposure correlated negatively with seminal plasma $\mathrm{Pb}(\mathrm{r}=0.06$, $p>0.05)$ and $\mathrm{Cd}(\mathrm{r}=0.26, p<0.05)$ concentrations. The environmentally exposed group had the highest mean $\mathrm{Pb}$ concentration of 19.7 (95\% CI 15.8-23.7) $\mu \mathrm{g} / \mathrm{dl}$ while the occupationally exposed group had the highest mean Cd concentration of $1.4(95 \%$ CI 1.2-1.7) $\mu \mathrm{g} / \mathrm{dl}$ as shown in Table 4. Of the pathozoospermics, 38 (38.4\%) had detectable levels of $\mathrm{Pb}$ in seminal plasma while 21 (21.2\%)

Table 3. Sperm parameters of pathozoospermic and normozoospermic men exposed and not exposed to toxicants

\begin{tabular}{|c|c|c|c|c|c|c|}
\hline \multirow[b]{2}{*}{$\begin{array}{l}\text { Sperm } \\
\text { parameter }\end{array}$} & \multicolumn{2}{|c|}{ Pathozoospermics $(n=99)$} & \multicolumn{3}{|c|}{ Normozoospermics $(n=201)$} & \multirow[b]{2}{*}{ Significance } \\
\hline & $\begin{array}{c}\text { Environmentally } \\
\text { or } \\
\text { occupationally } \\
\text { exposed }(n=49) \\
\text { mean }(95 \% C I)\end{array}$ & $\begin{array}{l}\text { Environmentally } \\
\text { or } \\
\text { occupationally not } \\
\text { exposed }(n=50) \\
\text { mean }(95 \% C I)\end{array}$ & Significance & $\begin{array}{l}\text { Environmentally } \\
\text { or } \\
\text { occupationally } \\
\text { exposed }(n=115) \\
\text { mean }(95 \% C I)\end{array}$ & $\begin{array}{l}\text { Environmentally } \\
\text { or } \\
\text { occupationally not } \\
\text { exposed }(n=86) \\
\text { mean }(95 \% C I)\end{array}$ & \\
\hline $\begin{array}{l}\text { Sperm } \\
\text { concentration } \\
(\text { million } / \mathrm{ml})\end{array}$ & $16.89(12.25-21.53)$ & $31.94(23.45-40.43)$ & $p=0.007^{*}$ & $80.52(69.34-91.7)$ & $81.03(72.1-89.96)$ & $p=0.94$ \\
\hline $\begin{array}{l}\text { Sperm } \\
\text { progressive } \\
\text { motility } \\
\text { percentage }\end{array}$ & $22.08(16.6-27.56)^{\#}$ & $22.62(18.76-26.48)^{\#}$ & $p=0.87$ & $48.42(46.57-50.27)$ & $52.48(50.2-54.76)$ & $p=0.007^{*}$ \\
\hline $\begin{array}{l}\text { Sperm } \\
\text { viability } \\
\text { percentage }\end{array}$ & $33.55(27.0-40.1)^{\#}$ & $38.92(33.77-44.07)^{\#}$ & $p=0.21$ & $56.67(54.48-58.86)^{\#}$ & $64.71(62.03-67.39)$ & $p=0.001 *$ \\
\hline $\begin{array}{l}\text { Sperm } \\
\text { morphology } \\
\text { (normal forms) } \\
\text { percentage }\end{array}$ & $21.46(17.2-25.72)$ & $28.00(23.35-32.65)$ & $p=0.045^{*}$ & $39.03(36.25-41.81)$ & $43.89(40.54-47.24)$ & $p=0.029 *$ \\
\hline
\end{tabular}

${ }^{*} p<0.05$. " below the WHO reference value

$p$ value was calculated using the independent sample t- test comparing the mean sperm parameters between exposed and not exposed pathozoospermic and normozoospermic men. 
Table 4. $\mathrm{Pb}$ and $\mathrm{Cd}$ levels in seminal plasma of different exposure categories

\begin{tabular}{|c|c|c|c|c|c|c|c|c|c|}
\hline \multirow{3}{*}{$\begin{array}{c}\text { Heavy } \\
\text { metal } \\
\text { concentra- } \\
\text { tion }\end{array}$} & \multicolumn{9}{|c|}{ Exposure category } \\
\hline & \multicolumn{3}{|c|}{ Environmental exposure } & \multicolumn{2}{|c|}{ Occupational exposure } & \multirow[b]{2}{*}{ Significance* } & \multicolumn{3}{|c|}{$\begin{array}{l}\text { Environmental and or } \\
\text { occupational exposure }\end{array}$} \\
\hline & $\begin{array}{c}\text { Positive } \\
n=80\end{array}$ & $\begin{array}{c}\text { Negative } \\
n=220\end{array}$ & Significance* $^{*}$ & $\begin{array}{l}\text { Positive } \\
n=112\end{array}$ & $\begin{array}{c}\text { Negative } \\
n=188\end{array}$ & & $\begin{array}{l}\text { Positive } \\
n=164\end{array}$ & $\begin{array}{c}\text { Negative } \\
n=136\end{array}$ & Significancex* \\
\hline $\begin{array}{l}\mathrm{Pb}(\mu \mathrm{g} / \mathrm{dl}) \\
{[\text { mean }} \\
(95 \% \mathrm{CI})]\end{array}$ & $\begin{array}{c}19.7(15.8- \\
23.7)\end{array}$ & $\begin{array}{c}14.3(12.5- \\
16.2)\end{array}$ & $p=0.1$ & $\begin{array}{c}15.9(13.1- \\
18.7)\end{array}$ & $\begin{array}{c}15.7(13.5- \\
17.8)\end{array}$ & $p=0.9$ & $\begin{array}{c}17.7(15.0- \\
20.4)\end{array}$ & $\begin{array}{c}13.5(11.2- \\
15.7)\end{array}$ & $p=0.1$ \\
\hline $\begin{array}{l}\mathrm{Cd}(\mu \mathrm{g} / \mathrm{dl}) \\
{[\text { mean }} \\
(95 \% \mathrm{CI})]\end{array}$ & $\begin{array}{c}0.7(0.6- \\
0.8)\end{array}$ & $\begin{array}{c}1.3(1.2- \\
1.5)\end{array}$ & $p=0.1$ & $\begin{array}{c}1.4(1.2- \\
1.7)\end{array}$ & $\begin{array}{l}1.0(0.9- \\
1.2)\end{array}$ & $p=0.3$ & $\begin{array}{l}1.2(1.1- \\
1.4)\end{array}$ & $\begin{array}{c}1.1(0.9- \\
1.3)\end{array}$ & $p=0.7$ \\
\hline
\end{tabular}

*Independent sample t- test $(p>0.05)$.

Table 5. Mean $\mathrm{Pb}$ and $\mathrm{Cd}$ concentrations in seminal plasma of pathozoospermic and normozoospermic males

\begin{tabular}{|c|c|c|c|c|c|c|}
\hline \multirow{3}{*}{$\begin{array}{c}\text { Heavy } \\
\text { metal } \\
\text { concentra- } \\
\text { tion }\end{array}$} & \multicolumn{3}{|c|}{ Pathozoospermic $(n=99)$} & \multicolumn{3}{|c|}{ Normozoospermic $(n=201)$} \\
\hline & \multicolumn{3}{|c|}{ Environmental and/or occupational exposure } & \multicolumn{3}{|c|}{ Environmental and/or occupational exposure } \\
\hline & $\begin{array}{l}\text { Positive } \\
(n=49)\end{array}$ & $\begin{array}{l}\text { Negative } \\
(n=50)\end{array}$ & Significance* & $\begin{array}{l}\text { Positive } \\
(n=115)\end{array}$ & $\begin{array}{l}\text { Negative } \\
(n=86)\end{array}$ & Significance* \\
\hline $\begin{array}{l}\mathrm{Pb}(\mu \mathrm{g} / \mathrm{dl}) \\
{[\text { mean }(95 \% \mathrm{CI})]}\end{array}$ & $19.2(13.9-24.5)$ & $15.3(11.2-19.6)$ & $p=0.5$ & $17.1(14.1-20.1)$ & $12.3(9.8-14.8)$ & $p=0.2$ \\
\hline $\begin{array}{l}\mathrm{Cd}(\mu \mathrm{g} / \mathrm{dl}) \\
{[\text { mean }(95 \% \mathrm{CI})]}\end{array}$ & $0.8(0.6-1.0)$ & $1.7(0.5-2.9)$ & $p=0.2$ & $1.4(1.2-1.6)$ & $0.8(0.6-1.0)$ & $p=0.2$ \\
\hline
\end{tabular}

*Independent sample t-test

had cadmium. Similarly, 77 (38.3\%) normozoo-spermics had lead in seminal plasma while the cadmium positive normozoospermics were 48 (23.9\%). Pathozoo-spermics had a higher $\mathrm{Pb}(17.25 \mu \mathrm{g} / \mathrm{dl})$ and $\mathrm{Cd}$ concen-tration $(1.25$ $\mu \mathrm{g} / \mathrm{dl})$ in seminal plasma than the normozoo-spermics $(\mathrm{Pb}=15.04 \mu \mathrm{g} / \mathrm{dl}, \mathrm{Cd}=1.15 \mu \mathrm{g} / \mathrm{dl})$ although the difference was not significant.

\section{Discussion}

It is estimated that about 10 to $12 \%$ of married couples in Sri Lanka are sub-fertile [9]. As men with known causes of infertility were excluded from this study, exposure to reproductive toxins needs to be explored as a possible contributory factor for infertility. The two reproductive toxicants specifically targeted in this study were $\mathrm{Pb}$ and $\mathrm{Cd}$ and the seminal plasma concentrations were measured as it is reported to be a better biomarker of male fertility than blood or plasma concentrations [10]. From the results of this study it is evident that environ-mental and occupational exposures are associated poor semen quality and with detectable levels of $\mathrm{Pb}$ and $\mathrm{Cd}$ in seminal plasma.

In our study, in the exposed group, normal morphology was significantly reduced among patho-zoospermics and normozoospermics while progressive motility and the viability of sperm were below the WHO reference value in pathozoopsermics. Even among the normozoospermics, sperm viability was less than the reference value of $58 \%$ in the exposed group. Several others have reported similar results $[11,12]$.

Lead and cadmium are known to disrupt the process of spermatogenesis, spermiogenesis and steroidogenesis in the testis by acting as chemicals affecting the hypothalamic-pituitary-gonadal axis or by directly damaging testicular tissue [13]. Exposure to toxicants causing an imbalance in the pro-oxidant and the anti-oxidant status in the testes leading to reactive oxygen species induced damage is another possible mechanism causing reduced sperm quantity and quality [14].

In this study the proportion of men with detectable $\mathrm{Pb}$ and $\mathrm{Cd}$ concentrations in seminal plasma (38.3\%) was similar to a study done in Singapore (37.5\%) [15]. The seminal plasma $\mathrm{Pb}$ concentration in our study was similar to an Indian study among oligozoospermic infertile men $(15.7 \mathrm{vs} 15 \mu \mathrm{g} / \mathrm{dl})$ but the $\mathrm{Cd}$ was much higher (1.18 vs $9.6 \mu \mathrm{g} / \mathrm{dl}$ ) in the Indian study [16]. In contrast these values were much higher when compared to the mean 
$\mathrm{Pb}$ and $\mathrm{Cd}$ levels reported as $1.24 \mu \mathrm{g} / \mathrm{dl}$ and $0.061 \mu \mathrm{g} / \mathrm{dl}$ respectively in the Singaporean study probably because those occupationally exposed to heavy metals were excluded [15]. It was noteworthy that even in those who reported as "not exposed" in our study, the mean lead $(13.4 \mu \mathrm{g} / \mathrm{dl})$ and cadmium $(1.1 \mu \mathrm{g} / \mathrm{dl})$ levels were higher than the Singaporean study. Thus inadvertent exposure through contaminated water, food and air is a possibility.

In a developing country like Sri Lanka with rapid infrastructure development, urbanization and industrialization, precautions to minimise environmental pollution and hazard reduction at work places are important. Larger epidemiological studies combined with basic sciences research are recommended to evaluate the link between toxicants and male infertility in Sri Lanka.

\section{Acknowledgments}

The study was funded by a research Grant (ASP/06/P/SCI/2011/12) from the University of Sri Jayewar-denepura.

\section{Conflicts of interest}

We declare that there are no conflicts of interest.

\section{References}

1. Benoff S, Hauser R, Marmar J, et al. Cadmium concentrations in blood and seminal plasma: correlations with sperm number and motility in three male populations (infertility patients, artificial insemination donors, and unselected volunteers). Mol Med 2009; 15: 248-62.

2. Carlsen E, Giwercman A, Keiding N, Skakkebak N. Evidence for decreasing quality of semen during the past 50 years. BMJ 1992; 305: 609-13.

3. Ten J, Mendiola J, Alberto M, et al. Occupational and lifestyle exposures on male infertility: a mini review. Open Reprod Sci J 2008; 1: 16-21.

4. Wong EP, Cheng CY. Impacts of environmental toxicants on male reproductive dysfunction. Trends Pharmacol Sci
2011; 32: 290-9.

5. Schrag SD, Dixon RL. Occupational exposures associated with male reproductive dysfunction. Annu Rev of Pharmacol Toxicol 1985; 25: 67-592.

6. Ileperuma OA. Environmental pollution in Sri Lanka. A review. J Natl Sci Found 2000; 28: 301-25.

7. World Health Organization. Laboratory manual for the examination and processing of the human semen. $5^{\text {th }}$ Edition, WHO Press, Geneva, Switzerland. 2010.

8. Hovatta O, Venalainen EJ, Kuvsimaki L, et al. Lead and cadmium concentrations in seminal plasma and spermatozoa, and semen quality in finnish men. Hum Reprod 1998; 13: $115-9$.

9. Ministry of Health, Population division, Nutrition and Welfare, Colombo, Sri Lanka. Report on the Fifth Asian and Pacific Population Conference, Bangkok, Thailand, Sri Lanka, country report. December 2002.

10. Minguez-Alarcon L, Mendiola J, Roca M, et al. Correlations between different heavy metals in diverse Body Fluids: Studies of human semen quality. Adv Urol 2012, Article ID 420893: 1-11

11. Golden AL, Moline JM, Chama NB. Male reproduction and environmental and occupational exposure: A review of epidemiologic methods. Salud Publica de Mêxico 1999; 41: 593-605.

12. Swan SH. Semen quality in fertile US men in relation to geographical area and pesticide exposure. Int J Androl 2006; 29: $62-8$.

13. Saradha B, Mathur P. Effect of environmental contaminants on male reproduction. Environ Toxicol Pharmacol 2006; 21: $34-41$.

14. Mathur PP, D'Cruz SC. The effect of environmental contaminants on testicular function. Asian J Androl 2011; 13: $585-91$.

15. Xu B, Chia SE, Tsakok M, Ong CM. Trace elements in blood and seminal plasma and their relationship to sperm quality. Reprod Toxicol 1993; 7: 613-8.

16. Pant N, Upadhyay G, Pandey S, et al. Lead and cadmium concentrations in the seminal plasma of men in general population: correlation with sperm quality. Reprod Toxicol 